Article

\title{
Extraction, Characterization and Antioxidant Activity in vitro of Proteins from Semen Allii Fistulosi
}

\author{
Min Zuo, Xiao-xiao Liu, Di Liu, Hang-yun Zhao, Lu-lu Xuan, Wen-xian Jiang and \\ Wan-zhong $\mathrm{Li} *$ (1)
}

School of Pharmacy, Weifang Medical University, Weifang 261053, Shandong Province, China; ZuoMin1026@163.com (M.Z.); liuxx@wfmc.edu.cn (X.L.); ld0928928@163.com (D.L.); zhy132104@163.com (H.Z.); xuanl11995@163.com (L.X.); jiangwenxian123@163.com (W.J.)

* Correspondence: liwz@wfmc.edu.cn; Tel.: +86-536-8462490

Received: 19 November 2018; Accepted: 5 December 2018; Published: 7 December 2018

\begin{abstract}
Semen Allii Fistulosi (PSAF) is the seed of Allium fistulosum L. of the Liliaceae family. The purpose of this study was to extract, characterize, and evaluate the antioxidant activity in vitro of proteins. Using single factor and orthogonal design, the optimum conditions of extraction were determined to be as follows: extraction time $150 \mathrm{~min}, \mathrm{pH} 8.5$, temperature $60^{\circ} \mathrm{C}$, and ratio $(v / w, \mathrm{~mL} / \mathrm{g}$ ) of extraction solvent to raw material 35. The isoelectric point of the $\mathrm{pH}$ was determined to be about 4.4 and 10.2, by measuring the protein content of PSAF solutions at different $\mathrm{pH}$ values. The amino acid composition of PSAF was determined by high performance liquid chromatography (HPLC), and the results suggested that the species of amino acids contained in the PSAF was complete. Sodium dodecyl sulphate polyacrylamide gel electrophoresis (SDS-PAGE) analysis showed the molecular weight was mainly between 40 and $55 \mathrm{kDa}$, and Fourier-transform infrared spectroscopy (FTIR) characterized prevalent protein absorption peaks. PSAF exhibited potent scavenging activities against DPPH assays, via targeting of hydroxyl and superoxide radicals, while chelating $\mathrm{Fe}^{2+}$ activity and demonstrating weak reducing power. This work revealed that PSAF possessed potential antioxidant activity in vitro, suggesting potential for use of PSAF as a natural antioxidant.
\end{abstract}

Keywords: Semen Allii Fistulosi; protein; extraction; characterization; antioxidant activity

\section{Introduction}

Allium fistulosum L. is a traditional Chinese vegetable and is one of the most commonly used vegetables in the daily life of Chinese families. The cultivated area of allium vegetables accounts for $10 \%$ of the total sown area of vegetables, and its yield accounts for $7 \%$ of the national agricultural output. A. fistulosum L. represents an important natural resource. A. fistulosum L. is an edible plant cultivated on a large scale, and according to the Compendium of Materia Medica, the roots, stems, flowers, and seeds of A. fistulosum L. could be used for medicinal purposes [1].

A. fistulosum L. has a variety of biological activities, such as antiseptic, anticancer, and antioxidative properties [2]. In particular, dry mature A. fistulosum L. seeds are often used for medicinal purposes, typically in the treatment of kidney deficiencies, vertigo, and other ailments [3]. Semen Allii Fistulosi extract is also known to prevent and treat myocardial ischemia [4]. Compounds imparting these effects are urgently needed [5], underlining the importance of the preliminary studies conducted here on plant protein antioxidant properties.

Oxidative stress is considered one of the causes of a variety of acute and chronic diseases, such as cancer, diabetes, cardiovascular disease, and Parkinson's disease [6]. Therefore, the development of antioxidants has become an important direction of the pharmaceutical field. Plant proteins demonstrate multiple biological activities, such as antioxidant [7], antitumor [8], immunomodulatory [9] and 
hypoglycemic activity [10]. There are some antioxidant proteins that have been extracted from plant material, such as seeds from Chinese chives [11], camellia [12], and Toona sinensis [13].

The constituents of Semen Allii Fistulosi (PSAF) are carbohydrates, proteins, fat and oil, palmitic acid adenosine, S-(cis-1-propenyl)-L-cysteine, $\beta$-sitosterol, etc [1,4]. The aim of the present work was to investigate the extraction of proteins from PSAF and preliminarily characterize the physicochemical properties and in vitro antioxidant activity of extracted proteins. In order to facilitate the extraction of water-soluble protein, PSAF was degreased during pretreatment. The solubilities of protein are affected by some conditions, such as $\mathrm{pH}$ value, ionic strength, temperature, salts, and solvent types. Thus, the proteins of $A$. fistulosum $\mathrm{L}$. seeds were extracted using the alkali water method. This work provides a scientific basis for the study of plant proteins as antioxidants, and has important practical significance and broad market potential.

\section{Results and Discussion}

\subsection{PSAF Extraction Process Parameters}

Proteins are ampholytes with positively and negatively charged groups, and their solubility varies with $\mathrm{pH}$. Thus, the appropriate $\mathrm{pH}$ value is helpful to protein extraction. With respect to the effect of $\mathrm{pH}$ on proteins from Semen Allii Fistulosi (PSAF) extraction rate, as shown in Figure 1A, when $\mathrm{pH}$ values were between 5 and 8 , the yield was observed to rise to a peak at $\mathrm{pH}$ 8.0. When $\mathrm{pH}$ exceeded 8.0, yields began to decrease, indicating the system was getting closer to isoelectric point for PSAF, which reduced yields by bringing about a decrease in the solubility. Thus, the ideal $\mathrm{pH}$ was determined to be $\mathrm{pH}=8.0$.
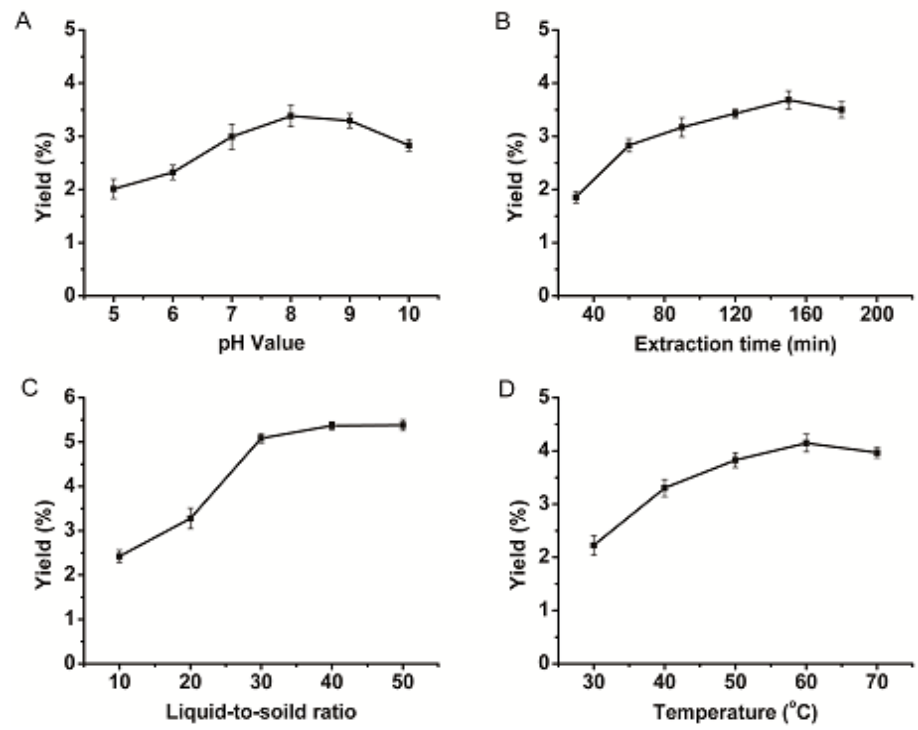

Figure 1. The effect of different extraction parameters: $\mathrm{pH}$ value (A), extraction time (B), liquid-to-solid ratio $(\mathbf{C})$, temperature $(\mathbf{D})$ on yield of PSAF.

As shown in Figure 1B, the effect of extraction time on PSAF extraction rate was investigated in this study. The yield of PSAF increased with the extraction time, reaching a maximum at $150 \mathrm{~min}$, after which showed slight decreases in yield. The length of time affects extraction efficiency and yield of proteins. The proteins denaturation caused the yield to decrease for a long duration [14]. Thus, the optimal extraction time was chosen as $150 \mathrm{~min}$.

Different ratios of liquid-to-solid affect solution viscosity, molecular diffusion, and protein dissolution [15,16]. With respect to the effect of liquid to solids ratio on extraction, as shown in Figure $1 C$, the PSAF yield rose clearly with an increasing ratio of liquid to material over the range of 10 to $30 \mathrm{~mL} / \mathrm{g}$, reaching a maximum value at a ratio of $40 \mathrm{~mL} / \mathrm{g}$. After that, yields stabilized. 
Considering the experimental cost and extraction efficiency, the optimal liquid material ratio was chosen as $30 \mathrm{~mL} / \mathrm{g}$.

The extraction temperature can affect the protein yield [11], which may cause the protein steric structure to stretch, and the molecular thermal motion to intensify. High temperatures may destroy the spatial conformation of the protein and may cause the natural conformation of the protein to disintegrate.

As shown in Figure 1D, when the temperature was raised from $30{ }^{\circ} \mathrm{C}$ to $60^{\circ} \mathrm{C}$, the yield was increased until it reached the maximum. However, when the temperature exceeded $60^{\circ} \mathrm{C}$, the yield was lowered. Based on the extraction efficiency and protein stability, $60^{\circ} \mathrm{C}$ was advisable to select an extraction temperature.

\subsection{Optimization for PSAF Extraction}

The results of the orthogonal test and extreme difference analysis are shown in Table 1. The influence by the factors on the extraction yield of PSAF increased in the order of: B (extraction time) $<\mathrm{A}$ ( $\mathrm{pH}$ value) $<\mathrm{D}$ (temperature) $<\mathrm{C}$ (liquid-to-solid ratio) according to the $\mathrm{R}$ values. Based on this analysis, and considering the PSAF extraction efficiency, the cost of energy and the feasibility of experiment, the optimum conditions of extraction were determined as follows: extraction time $150 \mathrm{~min}$, extraction $\mathrm{pH} 8.5$, extraction temperature $60^{\circ} \mathrm{C}$, and ratio $(v / w, \mathrm{~mL} / \mathrm{g})$ of extraction solvent to raw material 35.

Table 1. Analysis of $\mathrm{L}_{9}\left(3^{4}\right)$ test results.

\begin{tabular}{cccccc}
\hline No. & pH (A) & $\begin{array}{c}\text { Extraction } \\
\text { Time (B) }\end{array}$ & $\begin{array}{c}\text { Liquid-to-Solid } \\
\text { Ratio (C) }\end{array}$ & $\begin{array}{c}\text { Temperature } \\
\text { (D) }\end{array}$ & $\begin{array}{c}\text { Yield of PSAF } \\
\text { (\%) }\end{array}$ \\
\hline 1 & 1 & 1 & 1 & 1 & 4.41 \\
2 & 1 & 2 & 2 & 2 & 4.86 \\
3 & 1 & 3 & 3 & 3 & 6.29 \\
4 & 2 & 1 & 3 & 3 & 4.67 \\
5 & 2 & 2 & 1 & 1 & 4.94 \\
6 & 2 & 3 & 2 & 2 & 4.63 \\
7 & 3 & 1 & 2 & 2 & 6.11 \\
8 & 3 & 2 & 3 & 3 & 4.75 \\
9 & 3 & 3 & 1 & 1 & \\
K1 & 5.19 & 5.06 & 4.60 & 4.62 & \\
K2 & 4.74 & 4.85 & 4.68 & 5.20 & \\
K3 & 5.13 & 5.15 & 5.78 & 5.24 & \\
R & 0.44 & 0.30 & 1.18 & 0.62 & \\
\hline
\end{tabular}

Ki: the mean of the corresponding levels of protein yield at each factor $(\mathrm{i}=1,2,3)$; $\mathrm{R}$ : the extreme difference between different levels of a factor.

\subsection{Characterization of PSAF}

To more accurately determine the isoelectric point of the PSAF, values from $\mathrm{pH} 2$ to $\mathrm{pH} 12$ were sequentially set. As shown in Figure 2A, two distinct troughs were demonstrated around $\mathrm{pH}$ values of 5 and 10, indicating that there were different isoelectric points for PSAF. Subsequently, eight $\mathrm{pH}$ values at values intervals of 0.4 were taken near these two $\mathrm{pH}$ values for further detection. As shown in Figure 2B,C, the absorbance was minimal at $\mathrm{pH} 4.4$ and $\mathrm{pH} 10.2$, and isoelectric points for PSAF were identified to be 4.4 and 10.2. As the isoelectric point represents $\mathrm{pH}$ values wherein a given protein has its lowest solubility, this information is critical when determining protein utilization, especially in food processing $[17,18]$. 

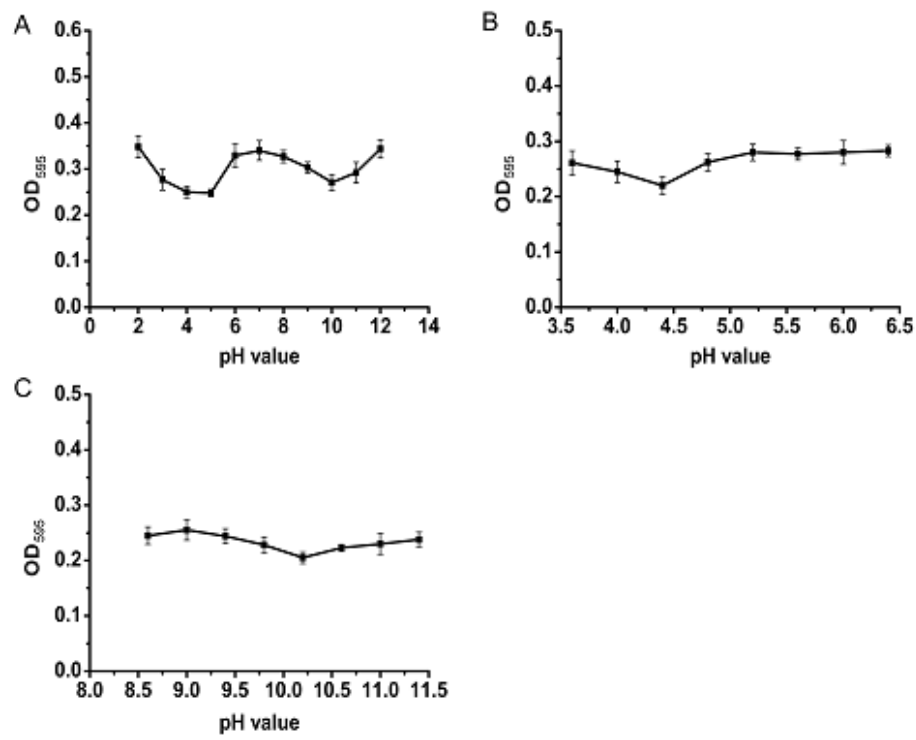

Figure 2. Absorbance of supernatants with different $\mathrm{pH}$ after reaction with Coomassie Brilliant Blue. (A) $\mathrm{pH} 2-12$; (B) $\mathrm{pH} 3.6-6.4$; (C) $\mathrm{pH} 8.6-11.4$.

With respect to amino acid composition, as shown in Table 2 and Figure 3, PSAF contained 17 different amino acids, and the species of amino acids were found to be relatively comprehensive, while isoleucine and leucine were found to be the limiting amino acids for PSAF. Glutamic acid was the highest among the whole amino acids, and the proportion of sulfur-containing amino acids, aromatic amino acids, and lysine in total amino acids was higher than the FAO/WHO reference value.

However, glutamic acid could combine with blood ammonia and transform into harmless glutamine, which participates in brain tissue metabolism and improves brain function [19]. The frequency of developmental issues in children increases due to a lack of dietary lysine [20]. Therefore, according to the protein complementation theory [21], PSAF could be used as a food fortifier to complement other proteins and improve the nutritional value of various foods.

Table 2. Analysis of amino acids composition (mg/100 mg) of PSAF.

\begin{tabular}{cccccc}
\hline Amino Acid & PSAF & FAO/WHO & Amino Acid & PSAF & FAO/WHO \\
\hline Aspartic acid & 6.33 & - & Valine & 4.49 & 4.96 \\
Serine & 4.47 & - & Cysteine \& methionine & 5.44 & 3.52 \\
Glutamic acid & 15.27 & - & Isoleucine & 2.01 & 4.0 \\
Glycine & 4.2 & - & Leucine & 4.43 & 7.04 \\
Alanine & 4.88 & - & Phenylalanine \& tyrosine & 6.74 & 6.08 \\
Histidine & 1.69 & - & Lysine & 6.22 & 5.44 \\
Arginine & 8.78 & - & FLAA & Ile & - \\
Proline & 2.26 & - & SLAA & Leu & - \\
Threonine & 2.81 & 4.0 & & & \\
\hline
\end{tabular}

FAO: Food and Agriculture Organization; WHO: World Health Organization; FLAA: first limiting amino acid; SLAA: second limiting amino acid. 

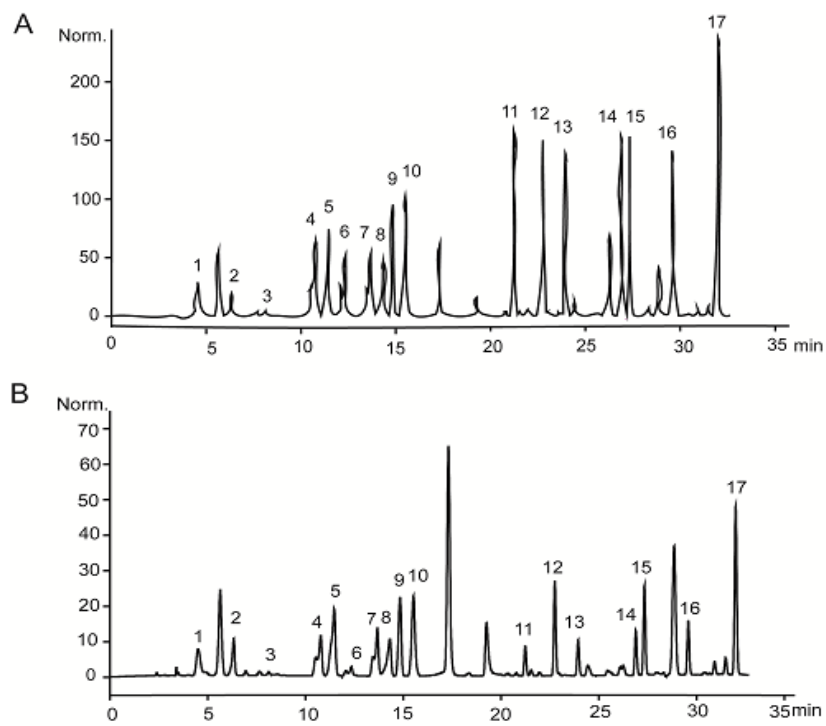

Figure 3. HPLC analysis of amino acids standard (A), and PSAF (B). Peaks: 1, Aspartic acid; 2, Glutamic acid; 3, Cysteine; 4, Serine; 5, Glycine; 6, Histidine; 7, Arginine; 8, Threonine; 9, Alanine; 10, Proline; 11, Tyrosine; 12, Valine; 13, Methionine; 14, Isoleucine; 15, Leucine; 16, Phenylalanine; 17, Lysine.

SDS-PAGE has become a widely used method for protein separation [22], and as the results show in Figure 4, three distinct bands were separated on gel. A darker band was located between $40 \mathrm{kDa}$ and $55 \mathrm{kDa}$, indicating that most of the PSAF protein was concentrated in this range, in comparison to the other two weaker bands at values of $15 \mathrm{kDa}$ and $10 \mathrm{kDa}$.

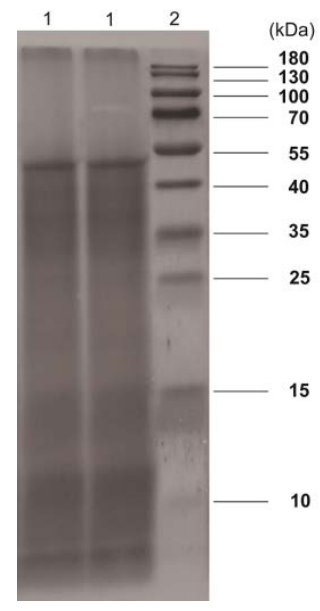

Figure 4. SDS-PAGE analysis of PSAF. Land 1: PSAF; Land 2: standard protein marker.

As shown in Figure 5, FT-IR analysis shows the absorption peak of N-H stretching vibration was in the range of 3400-3440 $\mathrm{cm}^{-1}$. The amide A band of SPAF appeared at $3291 \mathrm{~cm}^{-1}$, indicating that hydrogen bonds were formed between $\mathrm{N}-\mathrm{H}$ and $\mathrm{C}=\mathrm{O}$. The bands appearing at $2860-2930 \mathrm{~cm}^{-1}$ were due to the symmetric and asymmetric stretching vibration of $\mathrm{C}-\mathrm{H}$ found in the aliphatic chain of proteins and lipids [23]. The absorption bands appearing at 1655,1539 , and $1395 \mathrm{~cm}^{-1}$ were assigned to the amides I, II, and III, respectively [24]. Amide I was caused by the stretching vibration of C=O and which was often used for secondary structure analysis of proteins. Amide II mainly derived from $\mathrm{N}-\mathrm{H}$ bending vibration and followed by $\mathrm{C}-\mathrm{N}$ stretching vibration.

The bands observed at 1452 and $1242 \mathrm{~cm}^{-1}$ were attributed to the absorption of $\mathrm{CH}_{2}$ bending (scissors) vibration and C-N stretching modes [25]. The absorption peak at $1308 \mathrm{~cm}^{-1}$ vibrates at a range attributed to in-plane hydroxyl deformation [26]. The bands around 1168 and $1080 \mathrm{~cm}^{-1} \mathrm{may}^{-}$ be caused by antisymmetric stretching variation of C-O-C [25]. 


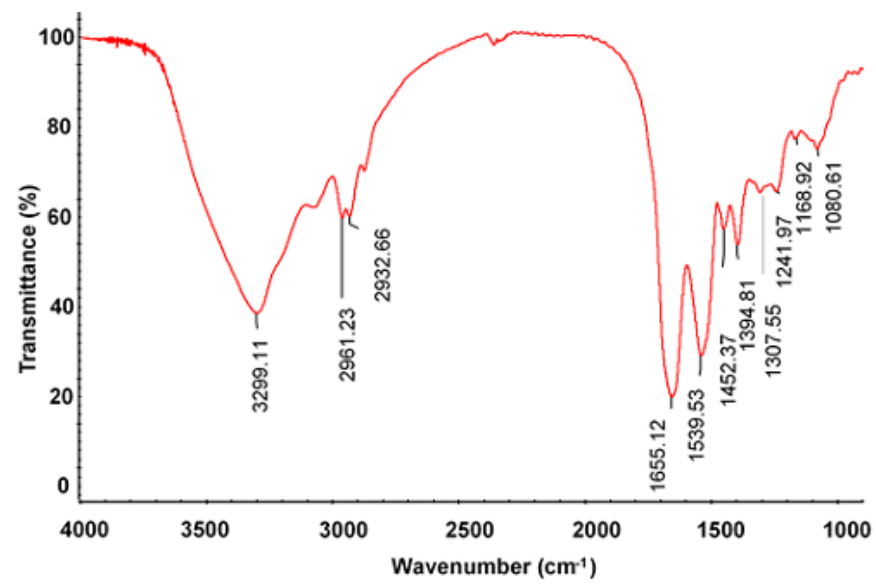

Figure 5. FT-IR spectra of PSAF.

\subsection{Antioxidant Activities in vitro}

DPPH represents a very stable free radical centered on nitrogen, and is widely used in the study of free radical scavenging ability of various antioxidants [27]. Figure 6A shows that DPPH scavenging ability increased within lower scope of concentration $(0-2 \mathrm{mg} / \mathrm{mL})$. The $\mathrm{IC}_{50}$ value is $1.43 \mathrm{mg} / \mathrm{mL}$. The change in antioxidant capacity was not obvious and tended to be stable at a concentration higher than $2 \mathrm{mg} / \mathrm{mL}$, which may be due to the ethanol solution restricted protein dissolution. The solubility of VC was relatively high, which may be one of the reasons why the scavenging effect of VC was better than that of PSAF.

A

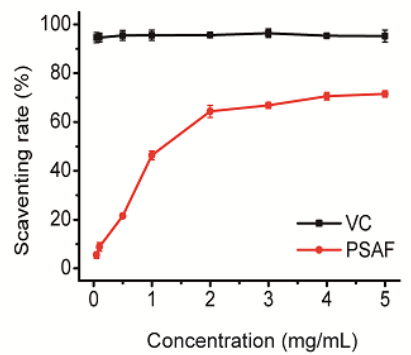

B

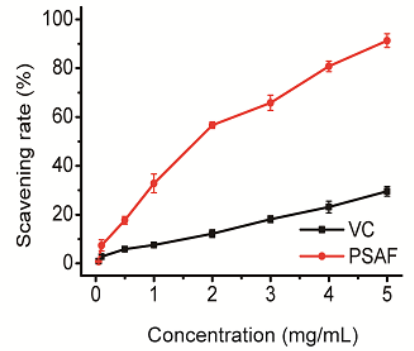

C

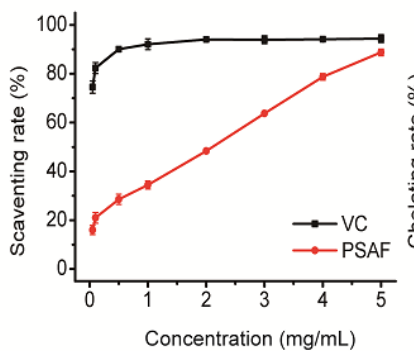

D

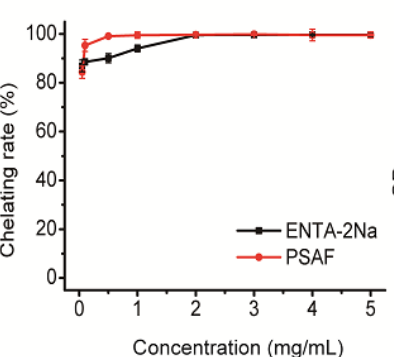

E

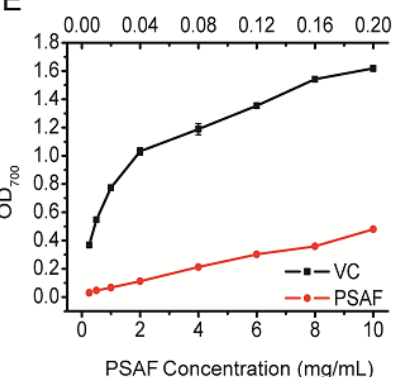

Figure 6. Antioxidant activities of PSAF in vitro. Scavenging effects on DPPH radical (A), hydroxyl radical (B), superoxide radical $(\mathbf{C})$ and $\mathrm{Fe}^{2+}$ chelating activity $(\mathbf{D})$ and reducing power $(\mathrm{E})$.

Hydroxyl radicals can interact with different molecules in cells and cause oxidative damage to sugars, amino acids, nucleic acids, and lipids [28]. In terms of hydroxyl scavenging, Figure 6B shows that there was a dose-dependent relationship between scavenging rate and concentration, and the scavenging rate rose with the increasing of concentration, with an $\mathrm{IC}_{50}$ value for PSAF of $1.37 \mathrm{mg} / \mathrm{mL}$. Interestingly, at certain concentrations, the scavenging rate of PSAF was higher than that of VC. 
Superoxide radicals can be metabolized to hydroxyl radicals by peroxidase in the body to hydroxyl free radicals, causing chronic and senile diseases [29]. The superoxide radical scavenging activity of PSAF was correlated with the concentration, and there was a tendency to approach or even exceed VC. At the maximum concentration of $5 \mathrm{mg} / \mathrm{mL}$, the clearance rate reached $88.76 \pm 0.55 \%$, and the $\mathrm{IC}_{50}$ value was $2.17 \mathrm{mg} / \mathrm{mL}$, indicating that PSAF has a certain ability to scavenge superoxide (Figure 6C).

$\mathrm{Fe}^{2+}$ can trigger free radical formation and thus cause lipid peroxidation or DNA damage [30]. The compounds with strong chelation ability for $\mathrm{Fe}^{2+}$ usually had functional groups, such as $-\mathrm{OH}$, $-\mathrm{SH},-\mathrm{COOH}, \mathrm{C}=\mathrm{O},-\mathrm{NR}_{2}$, and $-\mathrm{S}[31,32]$. The protein was provided with similar groups, which had the potential metal chelating capacity. With respect to $\mathrm{Fe}^{2+}$ chelating activity, as shown in Figure $6 \mathrm{D}$, within low concentrations $(<1 \mathrm{mg} / \mathrm{mL})$, PSAF showed a strong ability to chelate $\mathrm{Fe}^{2+}$, which was superior to that of VC. In particular, at a concentration of $0.5 \mathrm{mg} / \mathrm{mL}$, the chelation rate had exceeded $99 \%$ and the $\mathrm{IC}_{50}$ value was $0.006 \mathrm{mg} / \mathrm{mL}$.

As shown in Figure $6 \mathrm{E}$, the reducing power increased with the increasing of concentration. At the maximum concentration of $10 \mathrm{mg} / \mathrm{mL}$, the $\mathrm{OD}_{700}$ value was close to 0.5 . However, there was still a noticeable difference in reducing power between the PSAF and VC. Determination of reducing power is an important part of the antioxidant activity test. The greater the absorbance, the greater the reducing power and the antioxidant capacity.

\section{Materials and Methods}

\subsection{Materials and Equipment}

High-performance liquid chromatograph (Agilent 1260, Agilent Technology Ltd., Palo Alto, CA, USA), an ultraviolet spectrophotometer (UV-800A) from Shanghai Metash instruments Ltd. (Shanghai, China), and a Fourier transform infrared spectrometer (Nicolet is10) from Thermo Fisher Scientific Ltd. (Waltham, MA, USA) were used. Samples were freeze-dried with an FDU-1100 model from Eyela Ltd. (Tokyo, Japan). For molecular experiments, a double-sided vertical electrophoresis tank (JY-SCZ2, Beijing Junyi Electrophoresis Ltd., Beijing, China) and electrophoresis apparatus (DYY-6C, Beijing LiuYi Instrument Factory, Beijing, China) were used.

Semen Allii Fistulosi was obtained from Weifang Jian Xin pharmacy chain Co., Ltd. (Weifang, China). Coomassie brilliant blue G250 (Amresco 0615) and bovine serum albumin were obtained from Wako Pure Chemical Industries Ltd. (Osaka, Japan). The protein molecular weight markers were obtained from ThermoFisher Scientific Ltd. (Waltham, MA, USA). The standard reagents for analyzing amino acids were obtained from Sigma Ltd. (St. Louis, MO, USA). All other reagents used in the experiments were of analytical grade.

\subsection{Sample Pretreatment}

Dried raw material was ground into a powder and then pretreated with petroleum ether to degrease. The solid residue was separated from the solvent with filtration and dried at room temperature.

\subsection{Protein Content Determination}

According to the Coomassie Brilliant Blue method [33], a series of known concentrations ( 0.01 , $0.03,0.05,0.07$ and $0.09 \mathrm{mg} / \mathrm{mL}$ ) of bovine serum albumin were used to establish the standard curve. The obtained equation was $y=5.2794 x+0.0052$, coefficient of determination $r^{2}=0.9996$, where $x$ was the concentration and $y$ was the absorbance. The PSAF yield was calculated with the formula, yield $(\%, w / w)=\left(m_{1} / m_{2}\right) \times 100$, where $m_{1}$ was the mass of PSAF, and $m_{2}$ was the mass of dried sample.

\subsection{Extraction Optimization}

To determine the effects of $\mathrm{pH}$, extraction time, liquid-to-solid ratio, and temperature on extraction, single-factor extraction experiments were performed under the following conditions: $\mathrm{pH}$ of 5.0, 6.0, 
7.0, 8.0, 9.0, and 10.0, extraction time of 30, 60, 90, 120, 150, and $180 \mathrm{~min}$, liquid-to-solid ratio of 10:1, 20:1, 30:1, 40:1, and 50:1, temperature of $30,40,50,60$, and $70^{\circ} \mathrm{C}$. The effect of each factor on the yield was assessed to determine the optimum level. The initial extraction parameters were as follows: $\mathrm{pH} 8$, $120 \mathrm{~min}$ extraction time, liquid-to-solid ratio of $20 \mathrm{~mL} / \mathrm{g}$, and $40^{\circ} \mathrm{C}$ extraction temperature.

The raw material $(5 \mathrm{~g})$ was extracted with $0.02 \mathrm{M}$ phosphate buffer under the conditions described above. After extraction, the extracted solution was filtered and centrifuged. Then, the supernatant was concentrated at $60{ }^{\circ} \mathrm{C}$ under vacuum. Ammonium sulfate was added to the concentrated liquid to a final concentration of $95 \%$ and kept overnight at $4{ }^{\circ} \mathrm{C}$. After centrifugation, dialysis, and lyophilization, the crude PSAF was obtained.

The $\mathrm{pH}$ value, extraction time, liquid-to-solid ratio, and extraction temperature were selected based on the results of the single factor exploration experiment. An $\mathrm{L}_{9}\left({ }_{3}^{4}\right)$ orthogonal table was used to confirm the extraction process, and the factors and levels are shown in Table 3.

Table 3. Factors and levels for orthogonal design.

\begin{tabular}{ccccc}
\hline Factor Level & $\mathbf{p H}$ & $\begin{array}{c}\text { Extraction Time } \\
(\mathbf{m i n})\end{array}$ & $\begin{array}{c}\text { Liquid-to-Solid } \\
\text { Ratio }\end{array}$ & Temperature $\left({ }^{\circ} \mathbf{C}\right)$ \\
\hline 1 & 8.0 & 90 & $25: 1$ & 40 \\
2 & 8.5 & 120 & $30: 1$ & 50 \\
3 & 9.0 & 150 & $35: 1$ & 60 \\
\hline
\end{tabular}

\subsection{Characterization of PSAF Isoelectric Point and Amino Acid Composition}

To determine the isoelectric point, the PSAF solution was adjusted to different $\mathrm{pH}$ levels and centrifuged [34]. The protein content in the solution was measured, and the $\mathrm{pH}$ at the trough was determined. First, eleven integer $\mathrm{pH}$ values ( $\mathrm{pH}$ 2-12) were selected to determine. Then, $8 \mathrm{pH}$ values with a spacing of 0.4 were selected near the trough $\mathrm{pH}$ for measurement. Finally, the $\mathrm{pH}$ at the bottom of the curve was the isoelectric point of the protein.

Amino acids composition was determined according to the method [33]. PSAF was hydrolyzed with $6 \mathrm{M} \mathrm{HCl}$ at $110{ }^{\circ} \mathrm{C}$ for $24 \mathrm{~h}$ in a sealed tube with phenyl isothiocyanate (PITC) precolumn derivatization. The amino acids composition was analyzed using high-performance liquid chromatography (Agilent, USA). The chromatographic conditions were as follows: mobile phase (gradient elution), A: acetonitrile-0.1 M sodium acetate solution (3:97, v/v); B: acetonitrile-water (4:1, $v / v)$; column, Shiseido C18 $(4.6 \times 250 \mathrm{~mm}, 5 \mu \mathrm{m})$; flow rate, $1.0 \mathrm{~mL} / \mathrm{min}$; column temperature, $40{ }^{\circ} \mathrm{C}$; detector wavelength, $245 \mathrm{~nm}$.

\subsection{SDS-PAGE and FT-IR Spectra Analysis}

SDS-PAGE was run according to a previously described method [35]. PSAF samples were dissolved in distilled water, and the solutions were mixed with $20 \mu \mathrm{L}$ of sample buffer and heated at $100^{\circ} \mathrm{C}$ for $10 \mathrm{~min}$. Sample and marker were loaded onto precast polyacrylamide gel (resolving gel of $15 \%$ and stacking gel of $5 \%$ ). The electrophoresis experiments were run at $120 \mathrm{~V}$ for $35 \mathrm{~min}$ and subsequently ran at $150 \mathrm{~V}$ until the dye reached the bottom of the gel. The gel was stained with $0.1 \%$ Coomassie-Blue G-250.

Infrared (IR) analysis was performed using a Fourier transform infrared spectrophotometer. Approximately $2 \mathrm{mg}$ of the dried sample was mixed with an appropriate amount of $\mathrm{KBr}$, ground uniformly, and tableted using a tableting machine. IR spectrum was recorded in the frequency range of $4000-500 \mathrm{~cm}^{-1}$ [36].

\subsection{DPPH Radical Scavenging Assay}

PSAF was dissolved in deionized water to prepare a range of concentrations $(0.05,0.1,0.5,1,2,3$, 4 and $5 \mathrm{mg} / \mathrm{mL})$ and $200 \mu \mathrm{L}$ sample aliquots were taken and measured with $200 \mu \mathrm{L}$ of DPPH $(0.4 \mathrm{mM}$ in dehydrated alcohol). The absorbance was measured at $517 \mathrm{~nm}$, and Vitamin C (VC) was used as 
positive control [37]. DPPH radical scavenging activity was calculated using the following equation: Scavenging rate $(\%)=\left[1-\left(\mathrm{A}_{2}-\mathrm{A}_{1}\right) / \mathrm{A}_{0}\right] \times 100$, where $\mathrm{A}_{0}$ was the absorbance measured when the sample solution was replaced with distilled water, $\mathrm{A}_{1}$ was the absorbance measured when DPPH was replaced with dehydrated alcohol, and $\mathrm{A}_{2}$ represents absorbance measured in the sample solution.

\subsection{Hydroxyl and Superoxide Radical Scavenging Activity}

The hydroxyl radical content of the reaction solution can be detected at $520 \mathrm{~nm}$ [38]. VC was used as the positive control. Briefly, the reaction mixture contained $200 \mu \mathrm{L}$ sample solution, $200 \mu \mathrm{L}$ phosphate buffer $(1.5 \mathrm{mM}, \mathrm{pH} 7.4), 200 \mu \mathrm{L}$ safranine T solution $(360 \mu \mathrm{L} / \mathrm{mL}), 100 \mu \mathrm{L}$ EDTANa 2 -Fe solution $(12 \mathrm{mM})$ and $200 \mu \mathrm{L} \mathrm{H}_{2} \mathrm{O}_{2}$ solution $(3 \%, v / v)$. The reaction solution was placed at $37^{\circ} \mathrm{C}$ for $30 \mathrm{~min}$. Hydroxyl radical scavenging activity was calculated by equation: Scavenging rate $(\%)=\left(\mathrm{A}_{2}-\right.$ $\left.A_{1}\right) /\left(A_{0}-A_{1}\right) \times 100$, where $A_{0}$ was the absorbance measured when the sample solution and $\mathrm{H}_{2} \mathrm{O}_{2}$ solution was replaced with distilled water, $\mathrm{A}_{1}$ was the absorbance measured when the sample solution was replaced with distilled water, and $\mathrm{A}_{2}$ was the absorbance measured of the sample solution.

The scavenging ability of superoxide radical was measured by the slightly modified method [39]. Tris- $\mathrm{HCl}$ buffer $(16 \mathrm{mM}, \mathrm{pH} 8.0)$ was used as a reaction solvent. $300 \mu \mathrm{L}$ of the sample solution was mixed with NADH solution $(338 \mu \mathrm{M})$, NBT solution $(72 \mu \mathrm{M})$, and PMS $(30 \mu \mathrm{M})$ of $50 \mu \mathrm{L}$ respectively for $5 \mathrm{~min}$. The absorbance was measured at $560 \mathrm{~nm}$. VC was used as the positive control. The superoxide radical scavenging activity was calculated using the following equation: Scavenging rate $(\%)=\left[1-\left(\mathrm{A}_{2}-\mathrm{A}_{1}\right) / \mathrm{A}_{0}\right] \times 100$, where $\mathrm{A}_{0}$ was the absorbance measured when the sample solution was replaced with Tris-HCl buffer, $\mathrm{A}_{1}$ was the absorbance measured when the NBT was replaced with Tris- $\mathrm{HCl}$ buffer, $\mathrm{A}_{2}$ was the measured absorbance of the sample solution.

\section{9. $\mathrm{Fe}^{2+}$ Capacity Activity and Reducing Power Determination}

The extent of $\mathrm{Fe}^{2+}$ chelation was measured by the described method [40]. In brief, $200 \mu \mathrm{L}$ sample aliquots were mixed with $20 \mu \mathrm{L} \mathrm{FeCl}_{2}$ solution $(2 \mathrm{mM})$ and $40 \mu \mathrm{L}$ ferrozine solution $(5 \mathrm{mM})$ for $10 \mathrm{~min}$, and the absorbance at $562 \mathrm{~nm}$ was measured, with EDTA-2Na used as the positive control. The chelating activity $(\%)$ was calculated using the following equation: Chelating rate $(\%)=\left[1-\left(\mathrm{A}_{2}\right.\right.$ $\left.\left.-A_{1}\right) / A_{0}\right] \times 100$, where $A_{0}$ was the absorbance measured when the sample solution was replaced with distilled water, $\mathrm{A}_{1}$ was the absorbance measured when the $\mathrm{FeCl}_{2}$ was replaced with distilled water, and $\mathrm{A}_{2}$ was the absorbance of the sample solution.

The determination of reduction ability was based on the method by reference [41]. Two hundred microliters of phosphate buffer, $60 \mu \mathrm{L}$ sample aliquots, and $200 \mu \mathrm{L}$ potassium ferricyanide solution $(1 \%, w / v)$, were combined, and reacted at $50{ }^{\circ} \mathrm{C}$ for $20 \mathrm{~min}$. Two hundred microliters of trichloroacetic acid solution $(10 \%, w / v)$ was added to terminate the reaction. Two hundred microliters of reaction solution were taken, and $200 \mu \mathrm{L}$ of distilled water and $40 \mu \mathrm{L} \mathrm{FeCl}_{3}$ solution $(0.1 \%, w / v)$ were added, mixed, and after $10 \mathrm{~min}$ of reaction at room temperature the absorbance was measured at $700 \mathrm{~nm}$. VC served as a positive control.

\subsection{Statistical Analysis}

SPSS 17.0 software (SPSS Inc., Chicago, IL, US) was used for orthogonal design and its variance analysis used to determine a significant difference at $p<0.05$. The data are presented as mean \pm standard deviation (SD). All experiments were repeated three times.

\section{Conclusions}

In this study, the orthogonal design was used to optimize the extraction of protein from Semen Allii Fistulosi (PSAF) and after that, the protein extract was prepared by determined extraction conditions and ammonium sulfate precipitation. Then, isoelectric point measurement, HPLC, SDS-PAGE, and FT-IR were studied for preliminary characterization of PSAF. Finally, the antioxidant activity in vitro 
of PSAF were determined. These findings suggest that PSAF has potential antioxidant effects, and more study is merited.

Author Contributions: This study was conceived and designed by W.L.; X.L. contributed reagents/materials/analysis tools; The experiments were conducted by M.Z., D.L., H.Z., L.X.; W.J. analyzed the data. The manuscript was drafted by M.Z.; W.L. finalized the manuscript. All authors read and provided constructive comments on the manuscript.

Funding: This research was funded by the Natural Science Foundation of Shandong Province (ZR2018MH040 and ZR2017LH075), and Staring Foundation for Doctorate Research of Weifang medical university (2017BSQD50).

Conflicts of Interest: The authors declare no conflict of interest.

\section{References}

1. Yuan, Y.; Lai, W.; Yang, Q.; Sun, L.N.; Chen, W.S. Study on chemica constituents of Semen Allii Fistulosi (II). J. Pharm. Pract. 2010, 28, 426-428. [CrossRef]

2. Liu, J.T.; Wang, S.; Zhang, W.M.; Su, W.; Zhao, L. Review on Research Progress of Bioactive Constituents in Allium Species. Food Sci. 2007, 28, 348-350. [CrossRef]

3. Wei, Y.; Shao, A.J.; Cheng, M.; Fu, G.F.; Chen, M.L.; Lin, S.F. Study on the Characters and Microscopic Identification of Semen Allii Fistulosi and chinese chive seed. Mod. Chin. Med. 2012, 14, 20-21. [CrossRef]

4. Lai, W. Studies on the Active Constituents and Quality Control of the seeds of Allium fistulosum. Ph.D. Thesis, The Second Military Medical University, Shang Hai, China, 2010.

5. Devappa, R.K.; Makkar, H.P.; Becker, K. Nutritional, biochemical, and pharmaceutical potential of proteins and peptides from jatropha: Review. J. Agric. Food Chem. 2010, 58, 6543-6555. [CrossRef]

6. Sun, Y. Chemical composition activities of antioxidation and anticancer of Tetrastigma hemsleyanum Diels et Gilg. Ph.D. Thesis, Nanchang University, Jiang Xi, China, 2018.

7. Han, C.H.; Lin, Y.F.; Lin, Y.S.; Lee, T.L.; Huang, W.J.; Lin, S.Y.; Hou, W.C. Effects of yam tuber protein, dioscorin, on attenuating oxidative status and learning dysfunction in D-galactose-induced BALB/c mice. Food Chem. Toxicol. 2014, 65, 356-363. [CrossRef] [PubMed]

8. Chuethong, J.; Oda, K.; Sakurai, H.; Saiki, I.; Leelamanit, W. Cochinin B, a novel ribosome-inactivating protein from the seeds of Momordica cochinchinensis. Biol. Pharm. Bull. 2007, 30, 428-432. [CrossRef] [PubMed]

9. Chu, K.T.; Ng, T.B. Smilaxin, a novel protein with immunostimulatory, antiproliferative, and HIV-1-reverse transcriptase inhibitory activities from fresh Smilax glabra rhizomes. Biochem. Biophys. Res. Commun. 2006, 340, 118-124. [CrossRef] [PubMed]

10. Pan, D.; Zhang, D.; Wu, J.; Chen, C.; Xu, Z.; Yang, H.; Zhou, P. Antidiabetic, antihyperlipidemic and antioxidant activities of a novel proteoglycan from Ganoderma lucidum fruiting bodies on $\mathrm{db} / \mathrm{db}$ mice and the possible mechanism. PLoS ONE 2013, 8, e68332. [CrossRef] [PubMed]

11. Sun, J.; Yin, G.Y.; Ding, M.; Tao, Z.X. Study on extraction and antioxidant activity of protein from Chinese chive seed. Sci. Technol. Food Ind. 2014, 35, 291-294. [CrossRef]

12. Cao, W.; Pan, C.L.; Tang, W.; Sun, P.D. Extraction and antioxidant activity of camellia seed protein by different methods. Chin. Oils Fats 2014, 8, 26-30. [CrossRef]

13. Wang, S.R.; Meng, C.; Zhang, S.J.; Lu, Y.; Li, W.Z. Rapid Purification of Antioxidant Proteins from Toona sinensis Seeds Using Affinity Chromatography. Nat. Prod. Res. Dev. 2017, 1, 96-100. [CrossRef]

14. Pan, Y.; Lv, C.J.; X, C.L.; Pei, H.Y.; He, C.F.; Dong, Y.M.; Wang, C.T. Preliminary study on enzymatic extraction method and the effect of mung bean protein. Sci. Technol. Food Ind. 2010, 31, 238-241.

15. Shang, H.L.; Meng, X.; Zhang, T. Extraction and SDS-PAGE Analysis of Proteins from Job's Tears Seed. Chin. Agric. Sci. Bull. 2012, 28, 260-265. [CrossRef]

16. Fan, S.H.; Liu, Y.R.; Yuan, C. Preparation and Functional Properties of Protein Isolates from Pumpkin Seeds. Food Sci. 2010, 31, 97-100. [CrossRef]

17. Tan, S.H.; Mailer, R.J.; Blanchard, C.L.; Agboola, S.O. Canola proteins for human consumption: Extraction, profile, and functional properties. J. Food Sci. 2011, 76, R16-R28. [CrossRef] [PubMed]

18. Jun, H.; Hua, X.; Liang, L.I.; Ting, L.I.; Zhen, L.C. Enzymolysis of residue of rice and determination of its protein isoelectric point. Sci. Technol. Food Ind. 2008, 29, 174-176. [CrossRef]

19. Liu, G.; Wang, H.; Zhou, B.H. Analysis of 17 amion acids in Tricholoma matsutakes from Yunnan Province and its nutritional evaluation. Chin. J. Hosp. Pharm. 2008, 28, 552-554. [CrossRef] 
20. Tan, E.S.; Ying, Y.N.; Gan, C.Y. A comparative study of physicochemical characteristics and functionalities of pinto bean protein isolate (PBPI) against the soybean protein isolate (SPI) after the extraction optimisation. Food Chem. 2014, 152, 447-455. [CrossRef]

21. Wang, F.; Qiao, L.; Zhang, Q.Q.; Shen, B. Amino Acid Composition and Nutritional Evaluation of Mulberry Leaves. Food Sci. 2015, 36, 225-228. [CrossRef]

22. Hébert, E.M.; Raya, R.R.; Giori, G.S.D. Use of SDS-PAGE of cell-wall proteins for rapid differentiation of Lactobacillus delbrueckii subsp. lactis and Lactobacillus helveticus. Biotechnol. Lett. 2000, 22, 1003-1006. [CrossRef]

23. Jamin, N.; Dumas, P.; Moncuit, J.; Fridman, W.H.; Teillaud, J.L.; Williams, C.G.P. Highly resolved chemical imaging of living cells by using synchrotron infrared microspectrometry. Proc. Natl. Acad. Sci. USA 1998, 95, 4837-4840. [CrossRef] [PubMed]

24. Kong, J.; Yu, S. Fourier transform infrared spectroscopic analysis of protein secondary structures. Acta Biochim. Biophys. Sin. 2007, 39, 549-559. [CrossRef] [PubMed]

25. Chen, X.; Ru, Y.; Chen, F.; Wang, X.; Zhao, X.; Ao, Q.l. FTIR spectroscopic characterization of soy proteins obtained through AOT reverse micelles. Food Hydrocoll. 2013, 31, 435-437. [CrossRef]

26. Carpenter, J.F.; Crowe, J.H. An infrared spectroscopic study of the interactions of carbohydrates with dried proteins. Biochemistry 1989, 28, 3916. [CrossRef] [PubMed]

27. Zhang, Y.L.; Kong, L.C.; Yin, C.P.; Jiao, J.Q.; Xiao, W.X. Extraction optimization by response surface methodology, purification and principal antioxidant metabolites of red pigments extracted from bayberry (Myrica rubra) pomace. LWT-Food Sci. Technol. 2013, 51, 343-347. [CrossRef]

28. Spencer, J.P.; Jenner, A.; Aruoma, O.I.; Evans, P.J.; Kaur, H.; Dexter, D.T.; Jenner, P.; Lees, A.J.; Marsden, D.C.; Halliwell, B. Intense oxidative DNA damage promoted by L-dopa and its metabolites Implications for neurodegenerative disease. FEBS Lett. 1994, 353, 246-250. [CrossRef]

29. Li, S.; Shah, N.P. Antioxidant and antibacterial activities of sulphated polysaccharides from Pleurotus eryngii and Streptococcus thermophilus ASCC 1275. Food Chem. 2014, 165, 262-270. [CrossRef]

30. Liu, C.H.; Wang, C.H.; Xu, Z.L.; Wang, Y. Isolation, chemical characterization and antioxidant activities of two polysaccharides from the gel and the skin of Aloe barbadensis Miller irrigated with sea water. Process. Biochem. 2007, 42, 961-970. [CrossRef]

31. Jiang, C.; Li, X.; Jiao, Y.; Jiang, D.; Zhang, L.; Fan, B.; Zhang, Q. Optimization for ultrasound-assisted extraction of polysaccharides with antioxidant activity in vitro from the aerial root of Ficus microcarpa. Carbohydr. Polym. 2014, 110, 10-17. [CrossRef]

32. Liu, J.; Luo, J.; Ye, H.; Sun, Y.; Liu, Z.; Zeng, X. In vitro and in vivo antioxidant activity of exopolysaccharides from endophytic bacterium Paenibacillus polymyxa EJS-3. Carbohydr. Polym. 2010, 82, 1278-1283. [CrossRef]

33. Yang, Z.K.; Wang, X.L.; Long, S.H.; Hao, Z.B.; San, Z.Z.; Zhou, F.F. Determination of Protein in Soybean Stems and Leaves by Bradford Method. Hubei Agr. Sci. 2012, 51, 4610-4612. [CrossRef]

34. Min, J.H.; Li, J.K.; Chen, T. Study on the optimization of extraction technology of silkwormpupa protein. J. Shaanxi Normal Univ. 2009, 37, 92-96. [CrossRef]

35. Laemmli, U.K. Cleavage of structural proteins during the assembly of the head of bacteriophage T4. Nature 1970, 227, 680-685. [CrossRef]

36. Liu, X.; Hao, J.; Shan, X.; Zhang, X.; Zhao, X.; Li, Q.; Wang, X.; Cai, C.; Li, G.; Yu, G. Antithrombotic activities of fucosylated chondroitin sulfates and their depolymerized fragments from two sea cucumbers. Carbohydr. Polym. 2016, 152, 343-350. [CrossRef]

37. Yuan, Q.; Xie, Y.; Wang, W.; Yan, Y.; Ye, H.; Jabbar, S.; Zeng, X. Extraction optimization, characterization and antioxidant activity in vitro of polysaccharides from mulberry (Morus alba L.) leaves. Carbohydr. Polym. 2015, 128, 52-62. [CrossRef] [PubMed]

38. Smirnoff, N.; Cumbes, Q.J. Hydroxyl radical scavenging activity of compatible solutes. Phytochemistry 1989, 28, 1057-1060. [CrossRef]

39. Chen, B.J.; Shi, M.J.; Cui, S.; Hao, S.X.; Hider, R.C.; Zhou, T. Improved antioxidant and anti-tyrosinase activity of polysaccharide from Sargassum fusiforme by degradation. Int. J. Biol. Macromol. 2016, 92, 715-722. [CrossRef]

40. Decker, E.A.; Welch, B. Role of ferritin as a lipid oxidation catalyst in muscle food. J. Agric. Food Chem. 1990, 38, 674-677. [CrossRef] 
41. Xu, Y.; Niu, X.; Liu, N.; Gao, Y.; Wang, L.; Xu, G.; Li, X.; Yang, Y. Characterization, antioxidant and hypoglycemic activities of degraded polysaccharides from blackcurrant (Ribes nigrum L.) fruits. Food Chem. 2018, 243, 26-35. [CrossRef]

Sample Availability: Samples of the compounds are not available from the authors.

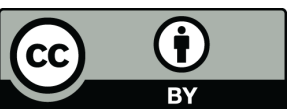

(C) 2018 by the authors. Licensee MDPI, Basel, Switzerland. This article is an open access article distributed under the terms and conditions of the Creative Commons Attribution (CC BY) license (http:/ / creativecommons.org/licenses/by/4.0/). 